\title{
Effect of Partial Solution Treatment Temperature on Microstructure and Tensile Properties of 440C Martensitic Stainless Steel
}

\author{
Junaidi Syarif $1, *\left(\mathbb{D}\right.$, Mohammad H. Yousuf ${ }^{1}\left(\mathbb{D}\right.$, Zainuddin Sajuri ${ }^{2, *}$, \\ Amir Hossein Baghdadi ${ }^{2, *(\mathbb{D})}$, Mahdi Merabtene ${ }^{1}$ and Mohd Zaidi Omar ${ }^{2} \mathbb{D}$ \\ 1 Department of Mechanical \& Nuclear Engineering, College of Engineering, University of Sharjah, \\ Sharjah 27272, UAE; mhd.h.yousuf@gmail.com (M.H.Y.); mahdimerabtene92@gmail.com (M.M.) \\ 2 Department of Mechanical and Manufacturing Engineering, Faculty of Engineering and Built Environment, \\ Universiti Kebangsaan Malaysia, Bangi 43600, Selangor, Malaysia; zaidiomar@ukm.edu.my \\ * Correspondence: sjunaidi@sharjah.ac.ae (J.S.); zsajuri@ukm.edu.my (Z.S.); \\ baghdadi.amirhossein@gmail.com (A.H.B.); Tel.: +9716-505-3945 (J.S.); Tel.: +603-8911-8016/8017 (A.H.B.)
}

Received: 22 April 2020; Accepted: 19 May 2020; Published: 22 May 2020

\begin{abstract}
The 440C martensitic stainless steel is considered to be among the hardest steels, owing to its high carbon content. Careful heat treatment of this material introduces multiple carbide particles, which can alter microstructure and mechanical properties. This study focused on the effect of austenitisation temperature on the microstructure and tensile properties of $440 \mathrm{C}$ steel. Austenitisation was performed on the austenite + carbide region, because $440 \mathrm{C}$ steel lacks a single-phase region. The steel was austenitised at two different temperatures; namely, $1160{ }^{\circ} \mathrm{C}$ and $950{ }^{\circ} \mathrm{C}$, and subjected to oil quenching. The as-quenched samples showed a typical lath martensite structure with retained austenite phase. The treatments at $1160{ }^{\circ} \mathrm{C}$ and $950{ }^{\circ} \mathrm{C}$ promoted the formation of $\mathrm{M}_{7} \mathrm{C}_{3}$ and $\mathrm{M}_{23} \mathrm{C}_{6}$ carbides, respectively. The austenite grains in the sample treated at $1160^{\circ} \mathrm{C}$ showed a higher growth rate than those in the sample treated at $950^{\circ} \mathrm{C}$. The sample treated at $1160^{\circ} \mathrm{C}$ showed low-fraction and a large-size carbide phase. The Zener pinning force decreased, thereby increasing the austenite grain growth in the sample treated at $1160{ }^{\circ} \mathrm{C}$. The hardness and $0.2 \%$ proof stress of the sample treated at $950{ }^{\circ} \mathrm{C}$ were higher than those of the sample treated at $1160{ }^{\circ} \mathrm{C}$, owing to the higher martensite content in the former. The strength-ductility balance of the sample treated at $950{ }^{\circ} \mathrm{C}$ was higher than that of the sample treated at $1160^{\circ} \mathrm{C}$. The decreased austenitisation temperature resulted in improved mechanical properties of the steel. Therefore, the austenitisation temperature alters the microstructure and mechanical properties of $440 \mathrm{C}$ steel.
\end{abstract}

Keywords: 440C stainless steel; martensite; retained austenite; carbide particle; mechanical properties; work hardening

\section{Introduction}

Martensitic stainless steel is high-performance steel among other engineering steels, such as transformation-induced-plasticity (TRIP) [1,2], dual-phase (DP) [3] and duplex stainless steels [4,5], and has excellent mechanical properties and high hardness. Its good corrosion resistance makes martensitic stainless steel suitable for various engineering applications requiring wear and corrosion resistance. In the family of martensitic stainless steel, $440 \mathrm{C}$ is the hardest steel; it is fabricated through the solution and precipitation of $1 \mathrm{wt} \%$ carbon [6,7], for applications in the tool industry. The carbon content is controlled up to $1 \mathrm{wt} \%$ to accommodate primary strengthening mechanisms, which include solid-solution strengthening and precipitation-hardening effects of chromium and molybdenum carbides [8]. The balance between strength and ductility of $440 \mathrm{C}$ martensitic stainless steel can 
be optimised through proper heat treatment procedures [9]. Austenitisation and transformation temperatures are important to forge the amount and distribution of undissolved carbides and retained austenite [10-12], affecting the mechanical performance and corrosion resistance [13,14]. 440C steel also contains a high chromium content of up to $17 \mathrm{wt} \%$, which enhances the corrosion resistance of steel $[15,16]$. Given these properties, $440 \mathrm{C}$ is highly recommended for heavy-duty applications, including valve components, races, ball bearings, gage blocks and automotive parts $[17,18]$.

Carbon and carbides not only increase the strength of steel, but can be used for controlling its microstructure, such as providing sites for nuclei and retarding austenite grain growth $[19,20]$. Based on the phase diagram of $440 \mathrm{C}$ steel [21], $\mathrm{M}_{7} \mathrm{C}_{3}$ and $\mathrm{M}_{23} \mathrm{C}_{6}$ carbides form precipitates at all temperature ranges; thus, performing a full solution treatment at which all carbides dissolve in the austenite $(\gamma)$ phase is difficult. Hence, a partial solution (PS) treatment of the $\gamma+$ carbide region is suggested to replace the full solution treatment. This method is also effective for modifying the $\gamma$ grains and improving the mechanical properties of steel.

The microstructures and mechanical properties of $440 \mathrm{C}$ steel depend strongly on the temperature and time of the PS treatment. For example, Salleh et al. [17] investigated the morphology of $\mathrm{M}_{7} \mathrm{C}_{3}$ carbide and the hardness of the steel after PS treatments of the $\gamma+\mathrm{M}_{7} \mathrm{C}_{3}+\mathrm{M}_{23} \mathrm{C}_{6}$ region at $1100{ }^{\circ} \mathrm{C}$ and $\gamma+\mathrm{M}_{7} \mathrm{C}_{3}$ region at $900^{\circ} \mathrm{C}$. After a prolonged PS treatment, the hardness of steel and $\mathrm{M}_{7} \mathrm{C}_{3}$ carbide decreased at $900{ }^{\circ} \mathrm{C}$, but increased at $1100{ }^{\circ} \mathrm{C}$. Although their work investigated the change in the microstructure and properties of steel due to PS treatment, most studies have focused on the tempering behaviour of steel after the PS treatment [22,23]. Moreover, detailed investigations have reported the effects of the PS treatment temperature and time on the microstructure and mechanical properties. The type and fraction of carbide are thought to change owing to the temperature of the PS treatment and modify the steel microstructure after rapid quenching to ambient temperature. Furthermore, the stability of the martensitic structure is strongly dependent on carbon solubility, which changes due to variations in the temperatures of the PS treatment, leading to alterations in the mechanical properties of the steel.

In this study, the effects of PS treatment temperature on the microstructure and tensile properties of $440 \mathrm{C}$ steel were investigated. Two different temperatures, namely, $950{ }^{\circ} \mathrm{C}$ and $1160{ }^{\circ} \mathrm{C}$, were used to reveal the phases of $\left(\gamma+\mathrm{M}_{23} \mathrm{C}_{6}\right)$ and $\left(\gamma+\mathrm{M}_{7} \mathrm{C}_{3}\right)$ during the PS treatment. The strength and ductility of the steel were also investigated relative to its work-hardening behaviour.

\section{Materials and Methods}

The material used in this study was $440 \mathrm{C}$ martensitic stainless steel, with the composition shown in Table 1 . The as-received steel was subjected by the manufacturer to soft annealing at $600{ }^{\circ} \mathrm{C}$, followed by air cooling.

Table 1. Chemical composition of the used steel (wt\%).

\begin{tabular}{cccccccccc}
\hline $\mathbf{C}$ & $\mathbf{C r}$ & $\mathbf{M o}$ & $\mathbf{M n}$ & $\mathbf{S i}$ & $\mathbf{N i}$ & $\mathbf{C u}$ & $\mathbf{P}$ & $\mathbf{S}$ & $\mathbf{F e}$ \\
\hline 1.04 & 16.5 & 0.43 & 0.34 & 0.33 & 0.2 & 0.08 & 0.028 & 0.016 & bal. \\
\hline
\end{tabular}

The samples were subjected to PS treatment at two different temperatures; namely, $1160^{\circ} \mathrm{C}$ and $950{ }^{\circ} \mathrm{C}$. For each temperature, the samples were held at four holding times; namely, 10, 30, 60, and $120 \mathrm{~min}$, followed by oil quenching. The proposed temperatures were selected in accordance with the phase diagram calculated by JMatPro ${ }^{\circledR}$ ver. 4.0, Sente software Ltd., Surrey, UK [21], as shown in Figure 1, where $\gamma+\mathrm{M}_{7} \mathrm{C}_{3}$ and $\gamma+\mathrm{M}_{23} \mathrm{C}_{6}$ regions existed at $1160^{\circ} \mathrm{C}$ and $950{ }^{\circ} \mathrm{C}$, respectively. The samples heat-treated at $1160{ }^{\circ} \mathrm{C}$ and $950{ }^{\circ} \mathrm{C}$ were referred to as 1160 -sample and 950-sample, respectively. The samples were then polished and etched using Vilella's reagent. Prior-austenite grain size was revealed by over-etching, using a solution of $4 \%$ picric acid and $1 \%$ hydrochloric acid. The microstructures and morphology of the carbides were observed by optical microscopy (OM) 
Olympus, Tokyo, Japan and scanning electron microscopy (SEM) Tescan-Vega, Brno, Czech Republic, equipped with energy-dispersive spectroscopy. X-ray diffraction (XRD) was performed to identify the phases and proportions of each phase in the as-quenched and tensile-tested samples. Equations (1) [24] and (2) were used to calculate the volume fraction of each phase, as follows:

$$
\begin{gathered}
F_{f c c}=I_{f c c} /\left(I_{f c c}+3.38 I_{b c c}\right) \\
\mathrm{F}_{\mathrm{all}}=\mathrm{F}_{\mathrm{fcc}}+\mathrm{F}_{\mathrm{bcc}}+\mathrm{F}_{\text {carbide }}=1
\end{gathered}
$$

where $I$ is the integrated intensity or the area under the peak [25], and $F$ is the volume fraction of the phase. The volume fractions and particle size of the carbides were determined using ImageJ software ver. 1.8.0_172, NIH Image, Bethesda, USA [26], an open-source image processing software that can be used to detect differences in colour values and identify and measure particles that exist in microscopic images. The measurement of carbide particle size included thousands of particles from the OM and SEM images. For hardness measurements, a Vickers microhardness tester was used with a $9.81 \mathrm{~N}$ weight loaded for $15 \mathrm{~s}$. The oil-quenched samples were machined to dumbbell shapes with a $\varnothing 6 \times 20 \mathrm{~mm}$ gauge dimension. The tensile test was conducted using an Instron 8801 load frame for samples heat-treated for 30 and $120 \mathrm{~min}$ at an initial strain rate of $10^{-3} \mathrm{~s}^{-1}$. Each sample was subjected to a tensile test by using three specimens.

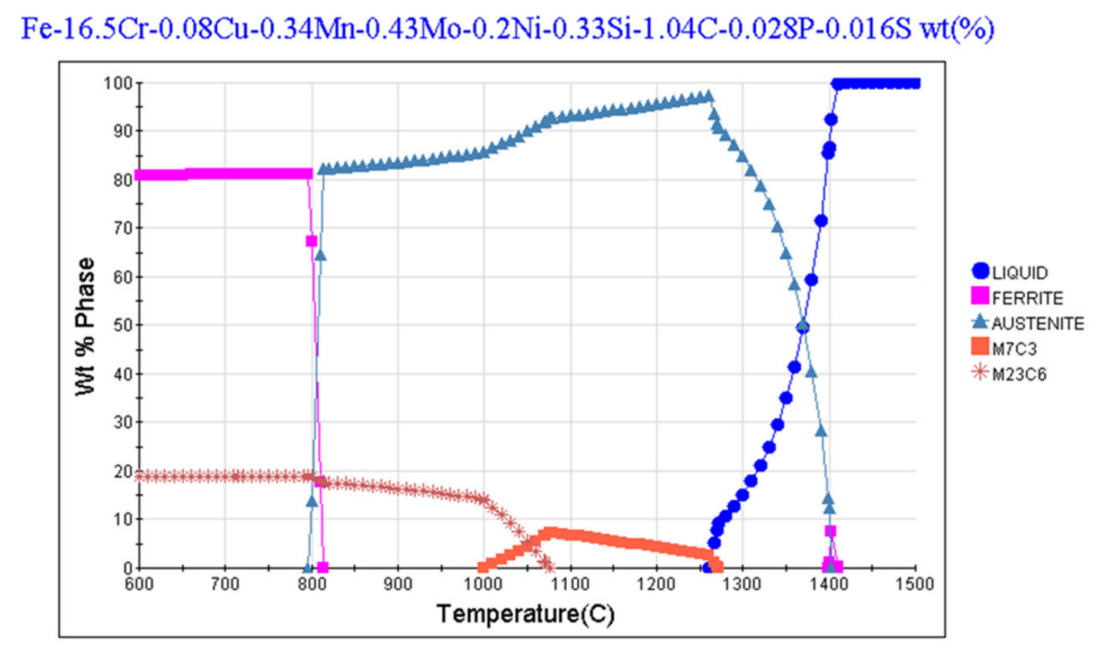

Figure 1. Phase equilibrium diagram of $440 \mathrm{C}$ martensitic stainless steel, obtained from JMatPro ${ }^{\circledR}$ simulation software.

\section{Results}

\subsection{Microstructure and Hardness of As-Quenched 440C}

Figure 2 shows the optical microstructures of 1160-sample and 950-sample. Both samples were subjected to PS treatment for $30 \mathrm{~min}$. A typical martensitic structure and insoluble carbide particles were observed within the samples. Prior-austenite grain boundaries were visible in the 1160-sample. Blocks or packets can be observed in the 950-sample. The 950-sample possessed more dispersed carbide particles than the 1160-sample. This finding could be due to the higher concentration of dissolved carbon in austenite at $1160{ }^{\circ} \mathrm{C}$ than at $950{ }^{\circ} \mathrm{C}$. The concentrations of dissolved carbon in austenite at $1160{ }^{\circ} \mathrm{C}$ and $950{ }^{\circ} \mathrm{C}$ were $0.60 \mathrm{wt} \%$ and $0.23 \mathrm{wt} \%$, respectively, as calculated by JMatPro ${ }^{\circledR}$. 

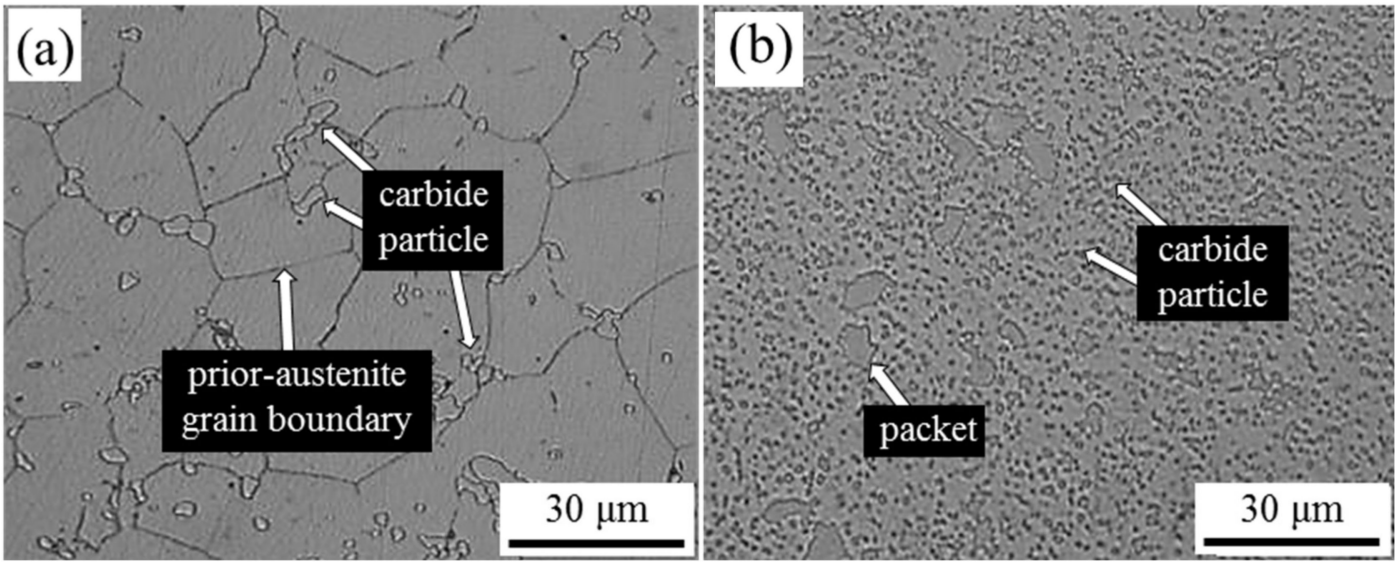

Figure 2. Optical micrographs: (a) 1160-sample and (b) 950-sample with the holding time of $30 \mathrm{~min}$ for the partial solution (PS) treatment.

Figure 3 shows the XRD diffractograms of the 1160-sample and 950-sample. The 1160-sample contained $\mathrm{M}_{7} \mathrm{C}_{3}$ carbides, along with the face-centered cubic (fcc) and body-centered cubic (bcc) phases. The 950-sample showed peaks for the $\mathrm{M}_{23} \mathrm{C}_{6}$ carbides, bcc and fcc phases. The fcc and bcc phases were verified as austenite and martensite, respectively. Table 2 summarises the volume fractions for each phase obtained by XRD and microscopic analysis for both samples, subjected to a PS treatment for $30 \mathrm{~min}$.
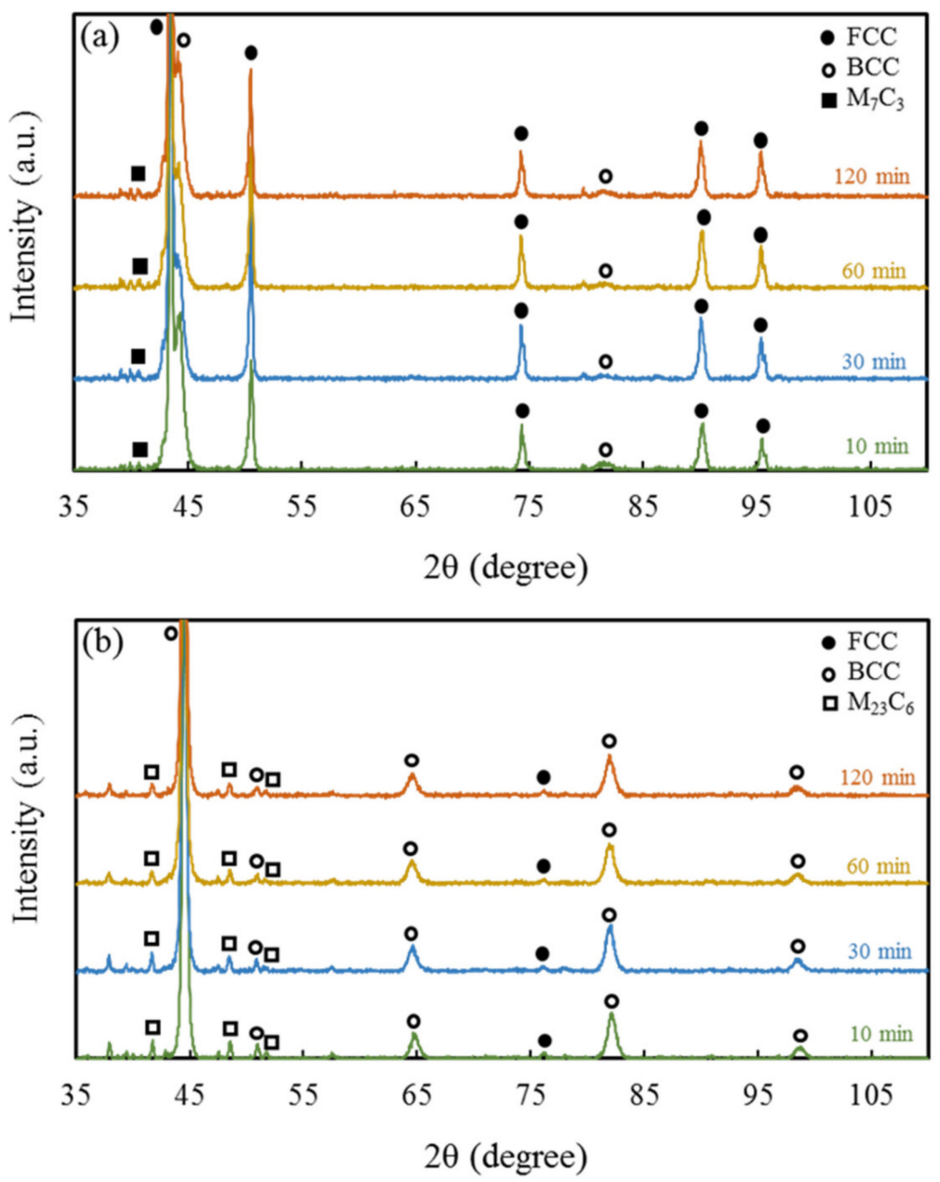

Figure 3. XRD diffractograms: (a) 1160-sample and (b) 950-sample. 
Table 2. Volume fractions (\%) of the present phases, with a holding time of $30 \mathrm{~min}$ for the PS treatment.

\begin{tabular}{ccc}
\hline Phase & $\mathbf{1 1 6 0}{ }^{\circ} \mathbf{C}$ & $\mathbf{9 5 0}^{\circ} \mathbf{C}$ \\
\hline $\mathrm{M}_{7} \mathrm{C}_{3}$ & 8 & 0 \\
$\mathrm{M}_{23} \mathrm{C}_{6}$ & 0 & 29 \\
$\mathrm{BCC}$ & 53 & 68 \\
$\mathrm{FCC}$ & 39 & 3 \\
\hline
\end{tabular}

The amount of carbide was almost constant in all ranges of holding time. A full martensitic structure is hard to obtain in practice from austenite upon oil quenching in $440 \mathrm{C}$, because the steel contains extremely high concentrations of $\mathrm{Cr}$ and $\mathrm{C}$. A retained austenitic structure was found accompanying the martensite. The amount of retained austenite differs depending on the martensite start (Ms) temperature, which is strongly affected by the concentration of dissolved carbon in the matrix $[27,28]$. Martensite is stabilised when the Ms temperature is higher than room temperature. Kobasko et al. [29] showed the variation in the Ms and martensite finish (Mf) temperatures, with respect to the carbon content of the steel. At $0.23 \mathrm{wt} \%$ dissolved carbon in the austenite, the Ms temperature and the gap of the Ms-Mf temperature were $400{ }^{\circ} \mathrm{C}$ and $100{ }^{\circ} \mathrm{C}$, respectively. Hence, the austenite phase transforms into the martensite phase at a sufficient cooling rate. On the other hand, the Ms temperature for $0.60 \mathrm{wt} \%$ dissolved carbon is located at $300{ }^{\circ} \mathrm{C}$, but the gap of the Ms-Mf temperature is higher than $300{ }^{\circ} \mathrm{C}$ for the steel, with $0.60 \mathrm{wt} \%$ dissolved carbon. Thus, the austenite phase cannot fully transform to martensite for the following reasons: the Ms is low, and the Mf is below room temperature. As a result, the values in Table 2 are justified in terms of martensite and austenite contents. Tsuchiyama et al. [30] reported that the grain growth of austenite in martensitic stainless steel can be suppressed by the insoluble carbides during PS treatment in the $\gamma+\mathrm{M}_{23} \mathrm{C}_{6}$ region. Figure 4 shows the relationship between the austenite grain size and the holding time during the PS treatment. Both samples showed that the austenite grain size increased with prolonged holding time. However, a significant difference in the increase in the grain size was observed between 950-sample and 1160-sample. The slope of the grain size of the 1160-sample is steeper than that of the 950-sample. Hence, the grain growth of austenite at $950^{\circ} \mathrm{C}$ was noticeably lower than that at $1160^{\circ} \mathrm{C}$.

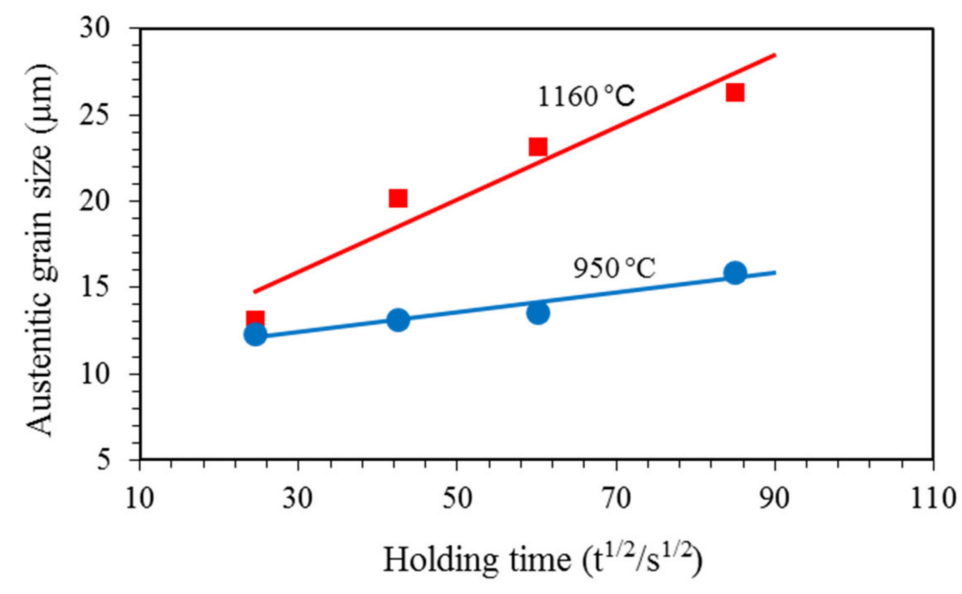

Figure 4. Relationship between the austenite grain size of 1160 sample and 950-sample and the holding time during the PS treatment.

Figure 5 shows the relationship between the size of the carbide particles of samples and the holding time of PS treatment. The figure also shows the particle size histograms for both samples. The measurement of carbide particle size was performed by considering thousands of particles in the $\mathrm{OM}$ and SEM images. Although the standard deviation of the 1160-sample was high, the average particle size for both samples was almost unchanged. As shown in Figure 5a, the particle size showed no response to the holding time for both austenitisation temperatures. The insoluble carbide particle 
for the 950-sample was almost three times smaller than that of the 1160-sample. The difference in the grain growth rate of austenite could be due to the Zener pinning effect. The drag pressure $P$ of the particle can be expressed as follows [31]:

$$
\mathrm{P}=3 \mathrm{Sf} / 2 \mathrm{R}
$$

where $S$ is the boundary energy $\left(0.8 \mathrm{~J} / \mathrm{m}^{2}\right)$ [32], $f$ is the fraction of particles, and $R$ is particle radius. The drag pressure of the 950-sample was higher than that of the 1160-sample. Thus, the grain growth in the 950-sample was suppressed, due to the Zener pinning effect of $\mathrm{M}_{23} \mathrm{C}_{6}$ particles.

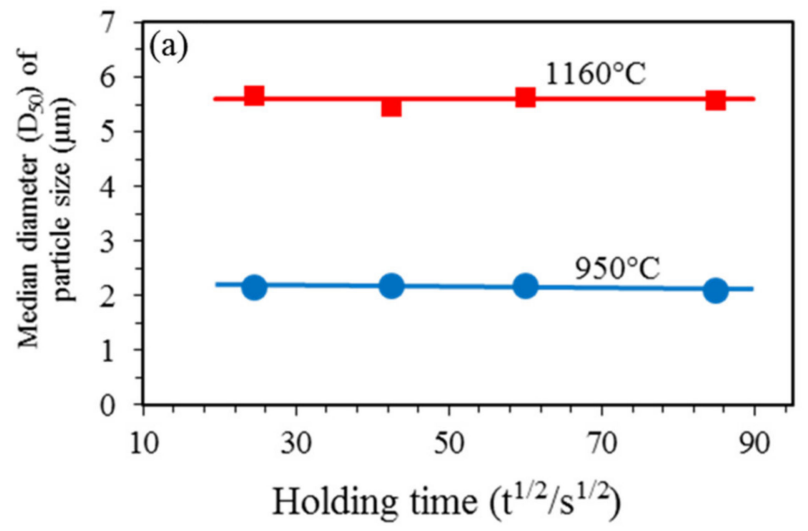

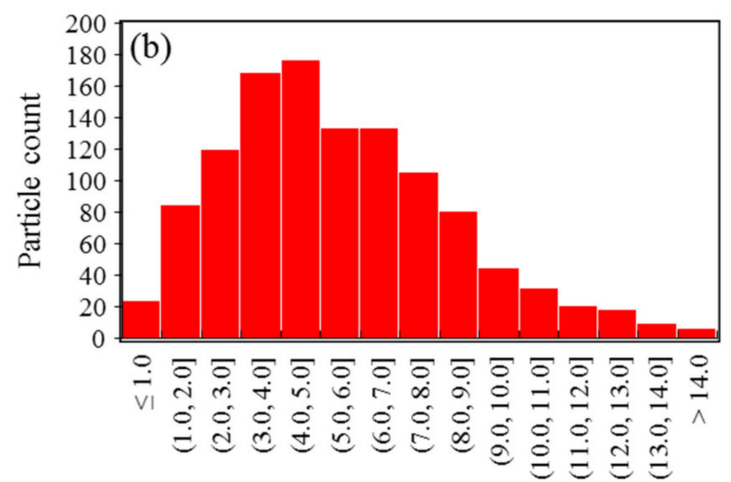

Particle diameter $(\mu \mathrm{m})$

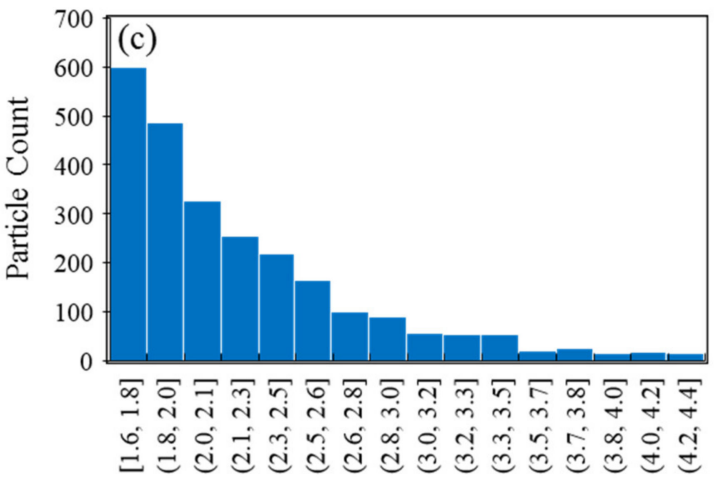

Particle diameter $(\mu \mathrm{m})$

Figure 5. (a) Relationship between the size of carbide particles and the holding time of the PS treatment. (b) Histograms of particle size measurement of 1160-sample and (c) 950-sample treated for $30 \mathrm{~min}$.

Figure 6 shows the changes in the hardness of both samples, with the holding time of PS treatment. The hardness of the as-received sample is also shown within the graph. Both temperatures significantly increased the hardness value compared with the as-received sample. The gap in the hardness between 1160-sample and 950-sample might be due to the difference in the martensite fraction of both samples (Table 2). The hardness of the 1160-sample showed an unnoticeable change along with the holding time. Meanwhile, the hardness of the 950-sample slightly increased with prolonged time, due to the increase in martensite fraction.

This finding was caused by the coarsening of austenite grains. As the austenite grain size increased upon solution treatment, the stability of austenite decreased [33,34]. Salleh et al. [17] reported that the hardness of the sample treated at a high temperature $\left(1100^{\circ} \mathrm{C}\right)$ was higher than that treated at a lower temperature $\left(900^{\circ} \mathrm{C}\right)$. However, the results of the present study differ from those of previous studies. A large difference was observed in the morphology and carbide fraction between $1100{ }^{\circ} \mathrm{C}$ and $1160{ }^{\circ} \mathrm{C}$. In the steel treated at $1100{ }^{\circ} \mathrm{C}$, full martensite and $10 \mathrm{wt} \% \mathrm{M}_{7} \mathrm{C}_{3}+\mathrm{M}_{23} \mathrm{C}_{6}$ carbides existed. On the other hand, retained austenite and $8 \mathrm{wt} \% \mathrm{M}_{7} \mathrm{C}_{3}$ carbide were contained in the martensitic 
matrix for the sample treated at $1160^{\circ} \mathrm{C}$. Thus, the hardness of the 1100 -sample was higher than that of the 1160-sample.

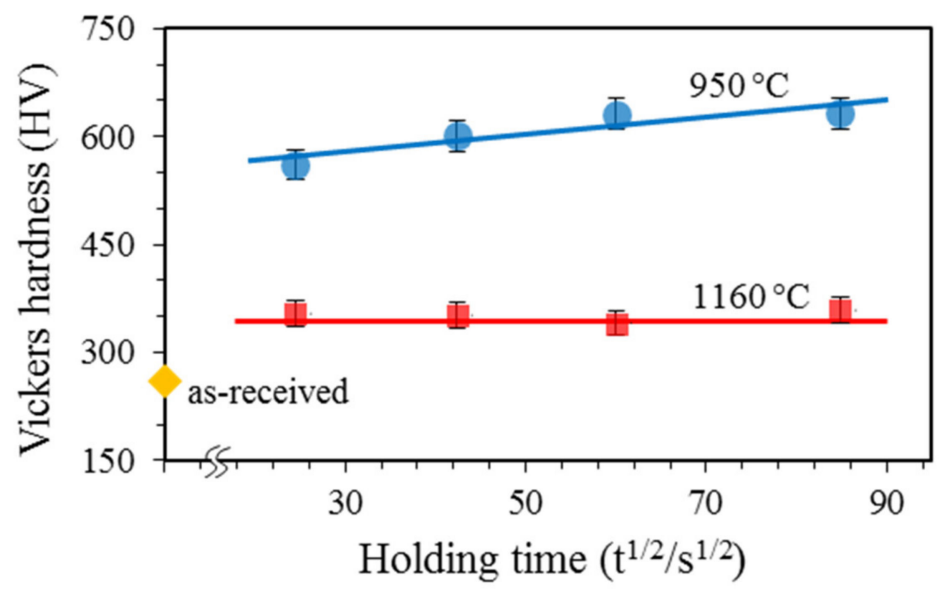

Figure 6. Effect of PS treatment holding time on the hardness of samples.

\subsection{Tensile Properties and Work-Hardening Behavior of As-Quenched 440C Steel}

The as-quenched samples were subjected to a tensile test to evaluate the effect of PS treatment on the mechanical properties of the as-quenched 440C steel. Figure 7a shows the engineering stress-strain curves of both samples. Both samples exhibited no necking phenomenon before rupture. Thus, the ultimate tensile strength and uniform elongation cannot be estimated. The fracture stress and total elongation were used instead of the ultimate tensile strength and uniform elongation, respectively, to calculate the balance of strength and ductility [35]. Figure $7 \mathrm{~b}$ shows the XRD results of the tensile-tested 1160-sample. The peaks of bcc and $\mathrm{M}_{7} \mathrm{C}_{3}$ phases existed in the post tensile-tested sample. This finding means that the retained austenite phase transformed into the martensitic phase during the tensile test.

Figure 8 shows different tensile properties, such as yield stress, fracture stress (a) and total elongation (b). The yield stress was shown by $0.2 \%$ proof stress. The yield and fracture stresses of the samples subjected to PS treatment increased compared with those of the as-received sample. The fracture and yield stresses of the 950-sample were higher than those of the 1160-sample. Hence, this trend matched the phenomenon obtained in the hardness test (Figure 6).

As shown in Table 2, the 950-sample is constructed by nearly full martensitic structure and $\mathrm{M}_{23} \mathrm{C}_{6}$ carbide, as matrix phase and precipitate, respectively. On the other hand, the matrix of the 1160-sample consists of martensitic structure and retained austenite phase, while $M_{7} C_{3}$ exists as the precipitate. The yield stress of the samples is determined by the constituent phases, such as the matrix and the precipitate. The matrices of both samples exhibit martensite and the strength of martensite is mainly due to carbon content and dislocation density [36]. The precipitation strengthening strongly depends on the size and fraction of the precipitate [37,38], thus, the contribution of the carbides on the yield stress of the samples will be less significant, owing to their large sizes. It means that the yield stress of the 950-sample can be mainly determined by dissolved carbon content and the dislocation density of martensite. However, the 1160-sample has more dissolved carbon content in martensite, but less martensite fraction, and contains retained austenitic phase when comparing with the 950-sample. The retained austenite is known as the soft phase in the steel [39] and will decrease the dislocation density of the 1160-sample. Therefore, this factor results in the decrease of the yield stress of the 1160-sample, compared to that of the 950-sample, even though the 1160-sample has higher carbon content in martensite. The austenite grains of the 950-sample grew under prolonged PS treatment holding time and increased the stability of martensite during quenching. This phenomenon led to the 
increased yield stress of the 950-sample. The total elongation of the 1160-sample was higher than that of the 950-sample.

(a)

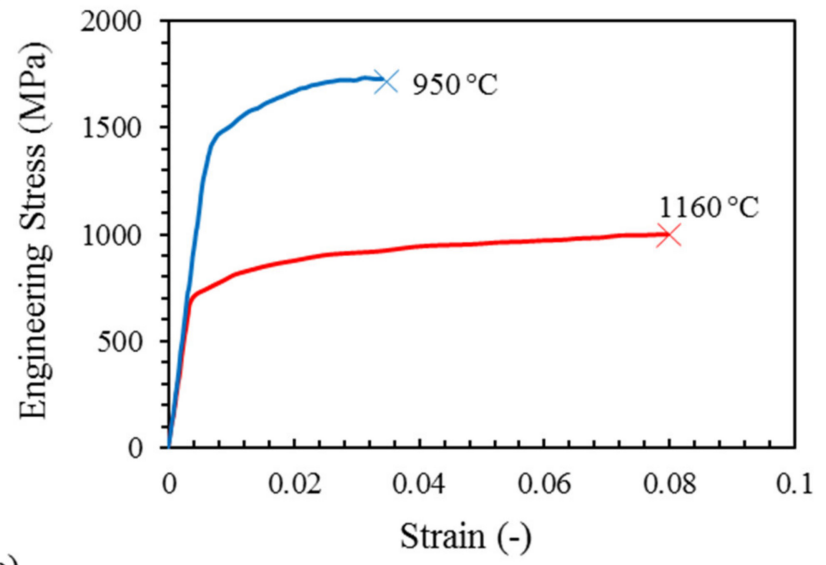

(b)

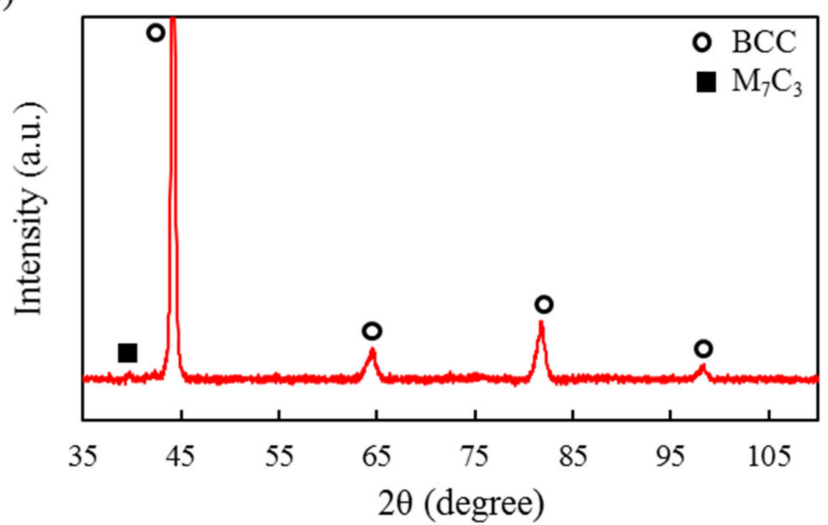

Figure 7. (a) Engineering stress-strain curve of samples treated for $30 \mathrm{~min}$ and (b) XRD diffractograms of tensile-tested 1160-sample.
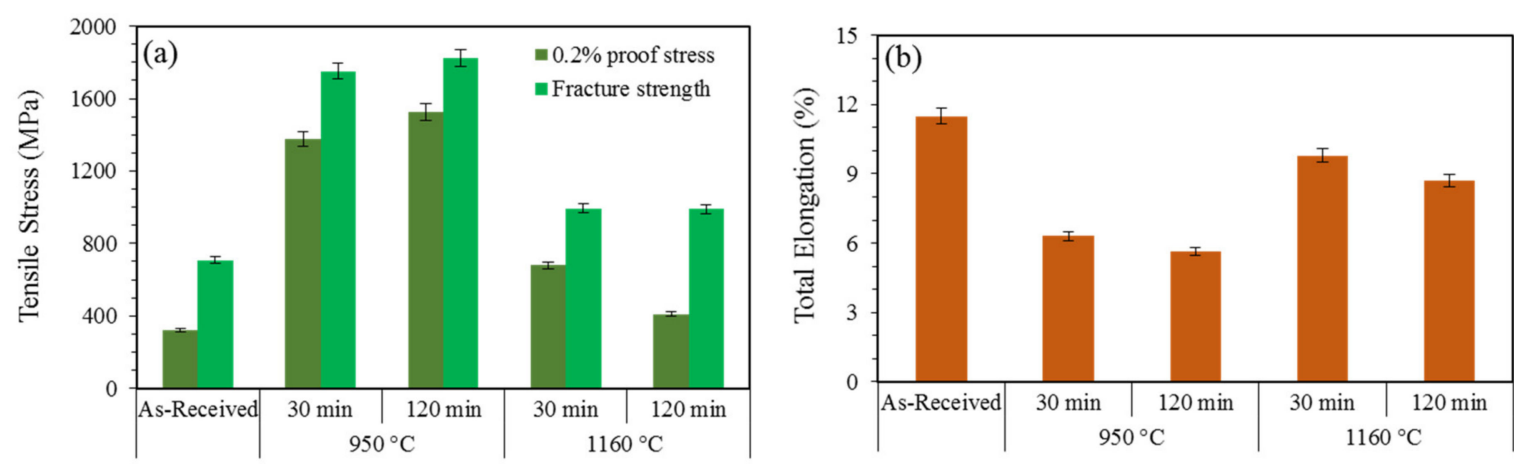

Figure 8. Tensile properties of samples heat-treated for 30 and $120 \mathrm{~min}$ : (a) yield and fracture stresses and (b) total elongation.

Based on the XRD results of the tensile-tested 1160-sample shown in Figure 7b, the retained austenite phase has transformed into the martensite structure upon the tensile test. Thus, the elongation of the 1160-sample increased due to the TRIP effect on the sample [40]. The stability of strength and ductility in Figure 9 is explained by the multiplication of fracture stress and total elongation. PS heat treatment improved the hardness, tensile properties and strength-ductility balance of $440 \mathrm{C}$ steel. 
The ductility of the 950-sample was lower than that of the 1160-sample. However, the strength-ductility balance for the 950-sample was the highest among the samples considered herein.

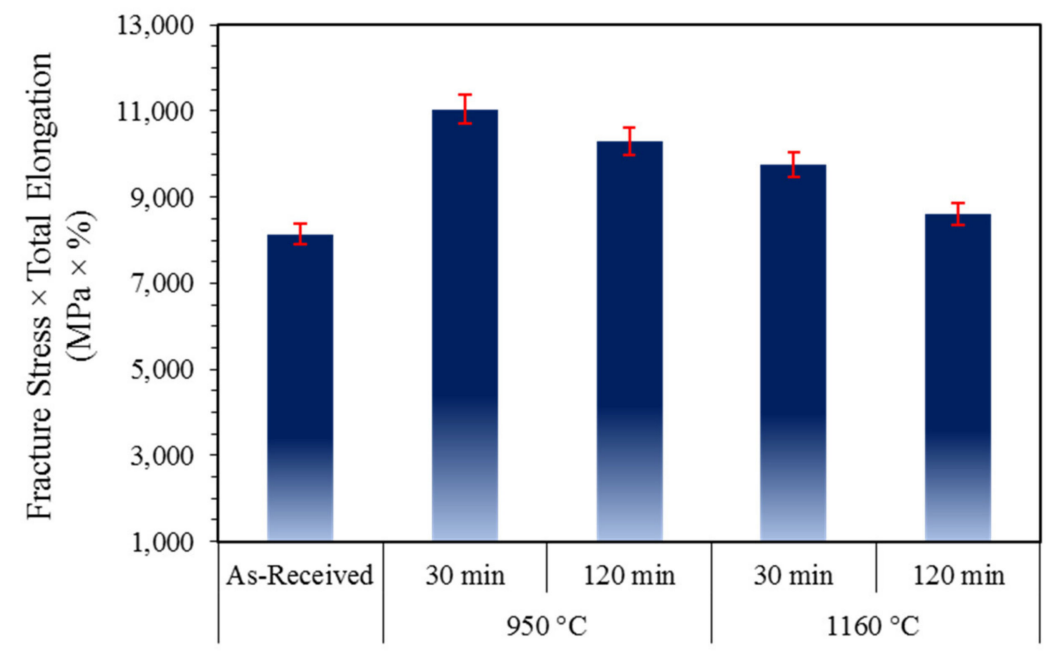

Figure 9. Strength-ductility balance of samples heat-treated for 30 and $120 \mathrm{~min}$.

Figure 10 shows the true stress $\left(\sigma_{t}\right)$ and work-hardening rate $\left(\mathrm{d} \sigma_{t} / \mathrm{d} \varepsilon_{t}\right)$ against the true strain $\left(\varepsilon_{t}\right)$. True stress was calculated assuming a constant gauge volume during deformation. Both samples showed a monotonous decrease in work hardening. Although the 950-sample showed a high work-hardening rate, the 1160-sample presented a stable plastic deformation. Furthermore, the sample fractured before the true stress and work-hardening rate lines intersected, indicating that both samples fractured in the plastic-deformation stability region without revealing a necking phenomenon.

Figure 11 shows the plot of $\ln \left(\mathrm{d} \sigma_{t} / \mathrm{d} \varepsilon_{t}\right)$ against $\ln \left(\sigma_{t}\right)$, for both samples. The plastic deformation behaviour substantially differed between both samples. The curves of $\ln \left(\mathrm{d} \sigma_{t} / \mathrm{d} \varepsilon_{t}\right)$ versus $\ln \left(\sigma_{t}\right)$ for both samples exhibited two slopes, although the constituent microstructures are different. It was also found that both samples have the same work-hardening exponent (from the first slopes), although the work-hardening mechanism would differ. For the 1160-sample, given that a high amount of soft-phased austenite remained in the sample, it could deform and transform into martensite at the first stage, because the retained austenite transformed into martensite when the steel was subjected to an applied load [41]. The plastic deformation behaviour of the 1160-sample was almost similar to that of a (ferrite + martensite) DP steel [42,43], even though the 1160-sample consisted of martensite and austenite. Then, the martensite deformed in the second stage after the knee (shown by an arrow). On the other hand, the work-hardening behaviour of the 950-sample would be affected by its constituent phases: martensite structure having dissolved carbon $(0.23 \mathrm{wt} \%)$ and high density of dislocation, and high fraction of $\mathrm{M}_{23} \mathrm{C}_{6}$ carbide.

In ultra-low carbon martensitic steel, the work-hardening behaviour was explained by a rapid annihilation of mobile dislocation, owing to the reaction among dislocations and the formation of cell structure by the remained dislocation upon the tensile test [44]. The dislocation density decreases abruptly $50 \%$ upon $2 \%$ tensile strain and is then maintained at the same amount until fracture. On the other hand, the increase of carbon content can decrease the annihilation rate of mobile dislocation and retard the formation of cell structure [36]. The dislocation density of the $0.32 \% \mathrm{C}$-martensitic steel decreases $15 \%$ on a $2 \%$ tensile strain and increases up to $105 \%$ on a $10 \%$ tensile strain, compared to that of the unstrained $0.32 \% \mathrm{C}$-martensitic steel. Furthermore, Zhuang et al. explained that the work hardening of steel with ferrite + cementite structure increased with increasing cementite's fraction and decreasing the cementite's size [45]. It is shown that the high work hardening rate $\left(\mathrm{d} \sigma_{t} / \mathrm{d} \varepsilon_{t}\right)$ of the 950-sample might be due to $0.23 \mathrm{wt} \%$ of dissolved carbon content and a high fraction of $\mathrm{M}_{23} \mathrm{C}_{6}$. This fact is indicated by the high work-hardening exponent in Figure 11. However, the 950-sample has a small work-hardening exponent after the knee. Although the deformation behaviour after the knee was not 
clarified yet, it is thought to be due to the increase and the accumulation dislocation at a matrix-carbide interface upon the tensile test. The accumulation of dislocation at the matrix-carbide would cause an interface decohesion between the matrix-carbide and formation of voids. Thus, it would lead to the decrease in work-hardening and an occurrence of fracture. This phenomenon explains the decrease of the tensile strength and the initiation of fracture in the ferrite-cementite steel [45].

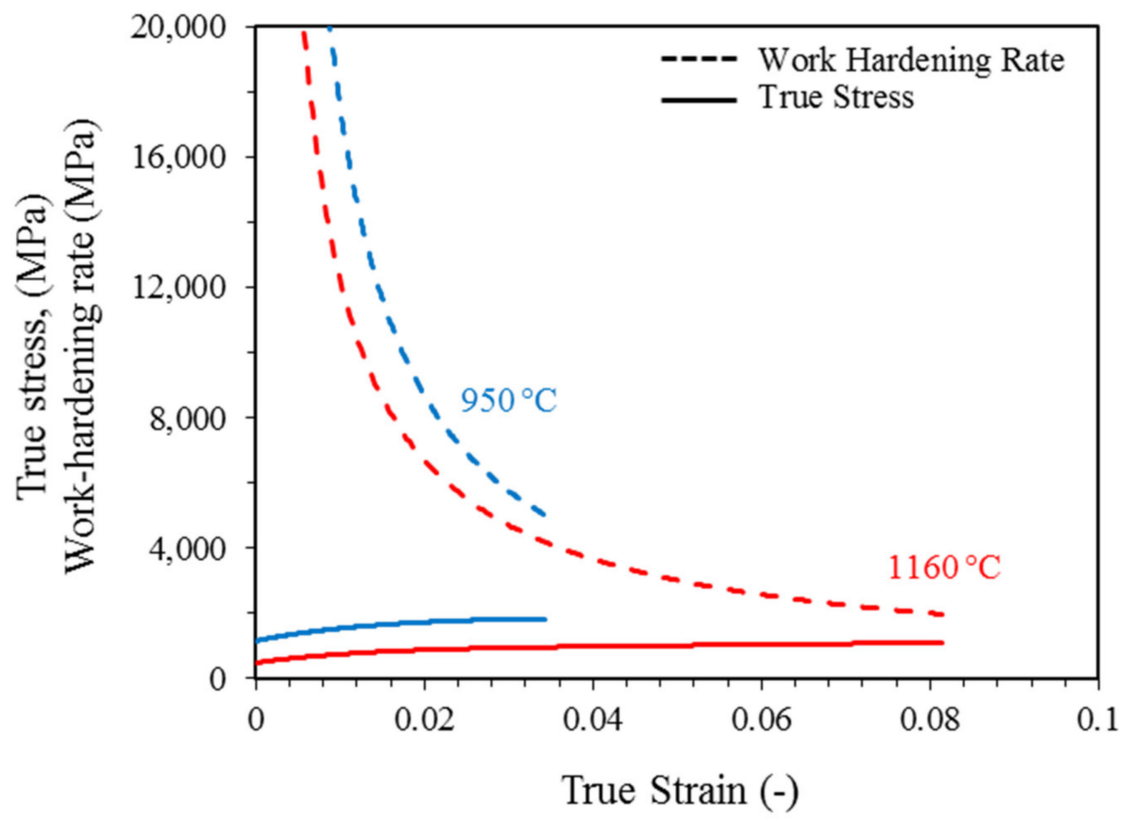

Figure 10. True stress and work-hardening rate of 1160-sample and 950-sample, heat treated for $30 \mathrm{~min}$.

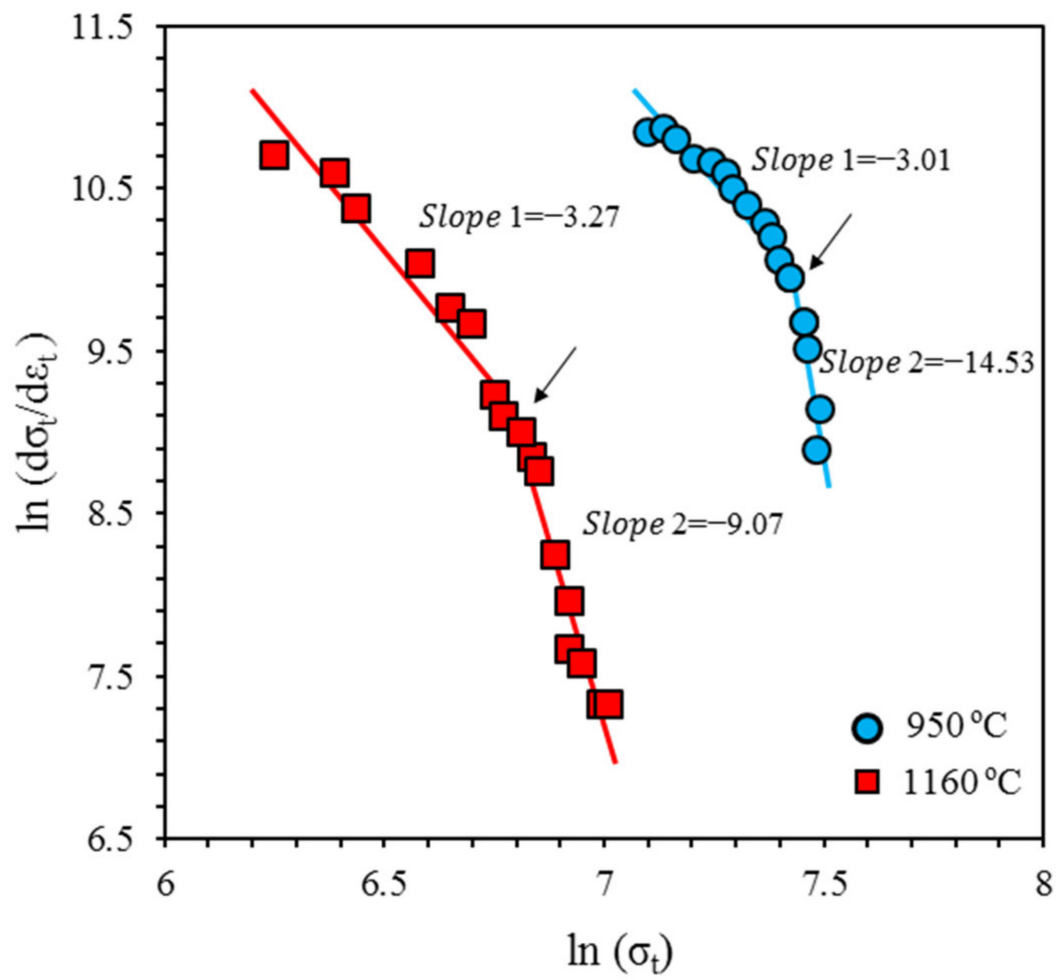

Figure 11. Comparison between 1160-sample and 950-sample in terms of $\ln \left(\mathrm{d} \sigma_{t} / \mathrm{d} \varepsilon_{t}\right)$ vs. $\ln \left(\sigma_{t}\right)$. 
The work hardening rate $\left(\mathrm{d} \sigma_{t} / \mathrm{d} \varepsilon_{t}\right)$ of the 1160-sample is estimated to be lesser than that of the 950-sample, because of the low fractions of martensite and $\mathrm{M}_{7} \mathrm{C}_{3}$. Although $0.60 \mathrm{wt} \%$ dissolved carbon in the martensite of the 1160-sample could increase the dislocation density on applying a load, it would be less significant, because the initial dislocation density was low owing to the low fraction of martensite. On the other hand, the retained austenite transformed to martensite on the tensile test, as indicated in Figure 11. The transformation of the retained austenite to martensite could increase the work-hardening rate $\left(\mathrm{d} \sigma_{t} / \mathrm{d} \varepsilon_{t}\right)$ of the steel and reveal the same work-hardening exponent with the 950-sample, having high fractions of martensite and carbide. Therefore, the transformation of the retained austenite could potentially lead to an increase in total elongation as shown in 9\%Ni steels [35].

From the aforementioned results, the temperature of PS treatment alters the microstructures of steel after quenching. The difference in the microstructure leads to a significant difference in the yield stress and the work hardening behavior on the tensile test.

Figure 12 shows the fracture surfaces of the 1160-sample and 950-sample, at two magnifications. The 1160-sample showed a grain boundary fracture accompanied by micro dimples (voids). In the 1160-sample, the transformation of the retained austenite to martensite during deformation led to ductile behaviour at the beginning and fracture at the grain boundaries. Numerous finely distributed voids were present in the 950-sample, due to small and distributed carbide particles that delaminated from the matrix.

The microstructure and tensile properties of 440C martensitic stainless steel strongly depend on the PS treatment. In engineering applications, steel is always subjected to tempering to enhance its ductility. The microstructure and mechanical properties after tempering vary, owing to differences in the temperature and time of PS treatment. If a phenomenon such as secondary hardening after tempering can be enhanced by changing the temperature of the PS treatment, then the mechanical properties of steel can be improved without changing its chemical composition.
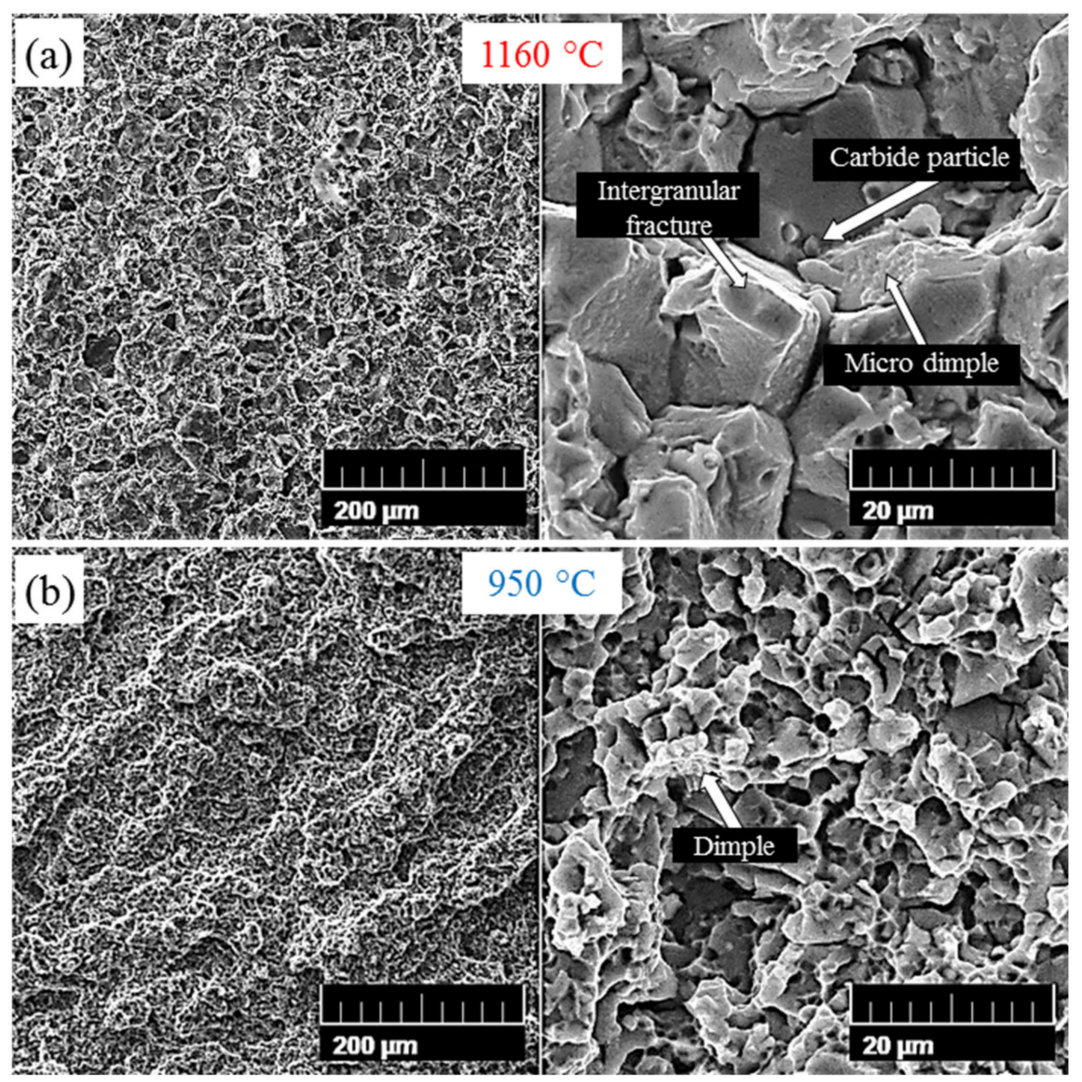

Figure 12. SEM images of fracture surface: (a) 1160-sample and (b) 950-sample, at different magnifications. 


\section{Conclusions}

The effect of PS treatment temperature on the microstructure and tensile properties of 440C steel was investigated, and the following conclusions were obtained:

1. After partial solution treatment, the phases that were present in the as-quenched sample included martensite, carbides and retained austenite. The sample heat treated at $1160{ }^{\circ} \mathrm{C}$ contained $\mathrm{M}_{7} \mathrm{C}_{3}$-type carbide and a high fraction of austenite. The sample heat treated at $950{ }^{\circ} \mathrm{C}$ contained $\mathrm{M}_{23} \mathrm{C}_{6}$ carbide, a high martensite content and a small amount of austenite.

2. During the $950{ }^{\circ} \mathrm{C}$ partial solution treatment, the grain growth rate of austenite was less than that at $1160{ }^{\circ} \mathrm{C}$. The growth of carbide particles was independent of the time of partial solution treatment for both temperatures, although the particle size for the sample treated at $950{ }^{\circ} \mathrm{C}$ was almost five times smaller than that at $1160^{\circ} \mathrm{C}$.

3. The sample treated at $950{ }^{\circ} \mathrm{C}$ showed higher hardness and strength compared with that at $1160{ }^{\circ} \mathrm{C}$. Both treatment temperatures resulted in improved strength relative to that of the as-received sample. The $950{ }^{\circ} \mathrm{C}$ treatment yielded an excellent strength-ductility balance, despite having a total elongation lower than that of the sample treated at $1160{ }^{\circ} \mathrm{C}$. Therefore, the partial solution treatment improved the mechanical properties of $440 \mathrm{C}$ steel.

4. The yield stress and the work-hardening behavior was influenced by the microstructures of the samples obtained upon the partial heat treatment and the quenching. The 950-sample showed high yield stress and work-hardening rate, owing to high fractions of martensite with dissolved carbon and of $\mathrm{M}_{23} \mathrm{C}_{6}$, whilst the 1160-sample has larger elongation, resulting from the transformation of the retained austenite to martensite.

Author Contributions: Conceptualization, J.S. and M.H.Y.; formal analysis, J.S., M.H.Y. and M.M.; investigation, J.S., M.H.Y. and M.M.; methodology, J.S., M.H.Y. and M.M.; project administration, J.S., Z.S. and M.Z.O.; supervision, J.S., Z.S. and M.Z.O.; visualization, J.S., Z.S. and A.H.B.; writing-original draft, J.S. and M.H.Y.; writing-review and editing, J.S., Z.S. and A.H.B. All authors have read and agreed to the published version of the manuscript.

Funding: The authors would like to acknowledge the joint research funding of this study by the University of Sharjah (grant number 1602040832-P) and the National University of Malaysia (grant number DIP-2014-024).

Conflicts of Interest: The authors declare no conflict of interest.

\section{References}

1. Uenishi, A. Development of Future Automobile Design Concept, NSafe ${ }^{\mathrm{TM}}$-AutoConcept. Nippon Steel Tech. Rep. 2019, 122, 7-12.

2. Funakawa, Y.; Nagataki, Y. High strength steel sheets for weight reduction of automobiles. JFE Tech. Rep. 2019, 24, 1-5.

3. Yamashita, T.; Toji, Y.; Kitahara, Y. Analysis technology of microsrtucture formation in high performance dual phase steel. JFE. Tech. Rep. 2017, 22, 25-29.

4. Cojocaru, E.M.; Raducanu, D.; Nocivin, A.; Cinca, I.; Vintila, A.N.; Serban, N.; Angelescu, M.L.; Cojocaru, V.D. Influence of Aging Treatment on Microstructure and Tensile Properties of a Hot Deformed UNS S32750 Super Duplex Stainless Steel (SDSS) Alloy. Metals 2020, 10, 353. [CrossRef]

5. Saeidi, K.; Alvi, S.; Lofaj, F.; Petkov, V.I.; Akhtar, F. Advanced mechanical strength in post heat treated SLM 2507 at room and high temperature promoted by hard/ductile sigma precipitates. Metals 2019, 9, 199. [CrossRef]

6. Zai, L.; Zhang, C.; Wang, Y.; Guo, W.; Wellmann, D.; Tong, X.; Tian, Y. Laser Powder Bed Fusion of Precipitation-Hardened Martensitic Stainless Steels: A Review. Metals 2020, 10, 255. [CrossRef]

7. Lin, Y.; Lin, C.-C.; Tsai, T.-H.; Lai, H.-J. Microstructure and mechanical properties of 0.63 C-12.7 Cr martensitic stainless steel during various tempering treatments. Mater. Manuf. Process. 2010, 25, 246-248. [CrossRef]

8. Huang, K.-T.; Chang, S.-H.; Wang, C.-K.; Chen, J.-K. Microstructures and mechanical properties of 440C stainless steel Strengthened with $\mathrm{TaC}$ via Vacuum sintering and heat Treatments. Mater. Trans. 2015, 56, 1585-1590. [CrossRef] 
9. Bush, R.; Gill, J.; Teakell, J. Heat Treatment Optimization and Fabrication of a 440C Stainless Steel Knife. JOM. 2016, 68, 3167-3173. [CrossRef]

10. Lu, S.-Y.; Yao, K.-F.; Chen, Y.-B.; Wang, M.-H.; Shao, Y.; Ge, X.-Y. Effects of austenitizing temperature on the microstructure and electrochemical behavior of a martensitic stainless steel. J. Appl. Electrochem. 2015, 45, 375-383. [CrossRef]

11. Zhou, M.; Xu, G.; Wang, L.; Yuan, Q. The varying effects of uniaxial compressive stress on the bainitic transformation under different austenitization temperatures. Metals 2016, 6, 119. [CrossRef]

12. Jia, T.; Ni, R.; Wang, H.; Shen, J.; Wang, Z. Investigation on the Formation of Cr-Rich Precipitates at the Interphase Boundary in Type 430 Stainless Steel Based on Austenite-Ferrite Transformation Kinetics. Metals 2019, 9, 1045. [CrossRef]

13. Choi, Y.-S.; Kim, J.-G.; Park, Y.-S.; Park, J.-Y. Austenitizing treatment influence on the electrochemical corrosion behavior of 0.3 C-14Cr-3Mo martensitic stainless steel. Mater. Lett. 2007, 61, 244-247. [CrossRef]

14. Mohammed, M.N.; Omar, M.Z.; Syarif, J.; Sajuri, Z.; Salleh, M.S.; Alhawari, K.S. Microstructural properties of semisolid welded joints for AISI D2 tool steel. J. Kejuruter. 2014, 26, 31-34. [CrossRef]

15. Kamimura, T.; Stratmann, M. The influence of chromium on the atmospheric corrosion of steel. Corros. Sci. 2001, 43, 429-447. [CrossRef]

16. Jiang, Z.; Feng, H.; Li, H.; Zhu, H.; Zhang, S.; Zhang, B.; Han, Y.; Zhang, T.; Xu, D. Relationship between microstructure and corrosion behavior of martensitic high nitrogen stainless steel 30Cr15Mo1N at different austenitizing temperatures. Materials 2017, 10, 861. [CrossRef]

17. Salleh, S.H.; Omar, M.Z.; Syarif, J.; Abdullah, S. Carbide formation during precipitation hardening of SS440C steel. Eur. J. Sci. Res. 2009, 34, 83-91.

18. Pan, L.; Kwok, C.T.; Lo, K.H. Friction-stir processing of AISI 440C high-carbon martensitic stainless steel for improving hardness and corrosion resistance. J. Mater. Process. Technol. 2020, 277, 116448. [CrossRef]

19. Vanherpe, L.; Moelans, N.; Blanpain, B.; Vandewalle, S. Pinning effect of spheroid second-phase particles on grain growth studied by three-dimensional phase-field simulations. Comput. Mater. Sci. 2010, 49, 340-350. [CrossRef]

20. Ji, G.; Gao, X.; Liu, Z.; Zhang, K. In situ observation and modeling of austenite grain growth in a Nb-Ti-bearing high carbon steel. J. Iron Steel Res. Int. 2019, 26, 292-300. [CrossRef]

21. Syarif, J.; Merabtene, M.; Yousuf, H.Y.; Omar, M.Z. Change in microstructure and mechanical properties ss440c steel by partial solution treatment. In Proceedings of the 4th International Metallurgical Engineering Conference, Istanbul, Turkey, 3 November 2016; Dakam: Istanbul, Turkey, 2016; pp. 55-59.

22. Salih, A.A.; Omar, M.Z.; Junaidi, S.; Sajuri, Z. Effect of different heat treatment on the SS440C martensitic stainless steel. Aust. J. Basic Appl. Sci. 2011, 5, 867-871.

23. Salleh, S.H.; Omar, M.Z.; Syarif, J.; Ghazali, M.J.; Abdullah, S.; Sajuri, Z. Investigation of microstructures and properties of 440C martensitic stainless steel. Int. J. Mech. Mater. Eng. 2009, 4, 123-126.

24. Solomon, N.; Solomon, I. Deformation induced martensite in AISI 316 stainless steel. Rev. Metal. 2010, 46, 121. [CrossRef]

25. Cullity, B.D.; Stock, S.R. Elements of X-ray Diffraction; Pearson: London, UK, 2001.

26. Schneider, C.A.; Rasband, W.S.; Eliceiri, K.W. NIH Image to ImageJ: 25 years of image analysis. Nat. Methods 2012, 9, 671-675. [CrossRef] [PubMed]

27. Wang, J.; van der Wolk, P.J.; van der Zwaag, S. Determination of martensite start temperature in engineering steels part I. Empirical relations describing the effect of steel chemistry. Mater. Trans. JIM 2000, 41, 761-768. [CrossRef]

28. Peng, F.; Xu, Y.; Li, J.; Gu, X.; Wang, X. Interaction of martensite and bainite transformations and its dependence on quenching temperature in intercritical quenching and partitioning steels. Mater. Des. 2019, 181, 107921. [CrossRef]

29. Kobasko, N.; Aronov, M.; Powell, J.; Vanas, J. Intensive Quenching of Steel Parts: Equipment and Method. In Proceedings of the 7th IASME/WSEAS International Conference on Health Transfer, Thermal Engineering and Environment, Moscow, Russia, 20-22 August 2009; pp. 20-22.

30. Tsuchiyama, T.; Takaki, S.; Nakamura, S. Austenite grain size control by insoluble carbide in martensitic stainless steels. Tetsu-Hagané 1995, 81, 147-152. [CrossRef]

31. Shan, G.B.; Chen, Y.Z.; Gong, M.M.; Dong, H.; Li, B.; Liu, F. Influence of $\mathrm{Al}_{2} \mathrm{O}_{3}$ particle pinning on thermal stability of nanocrystalline Fe. J. Mater. Sci. Technol. 2018, 34, 599-604. [CrossRef] 
32. Rodriguez-Ibabe, J.M.; López, B. Thermomechanical processing and role of microalloying in eutectoid steels. In Advanced Steels; Springer: Berlin, Germany, 2011; pp. 475-484.

33. Takaki, S.; Fukunaga, K.; Syarif, J.; Tsuchiyama, T. Effect of grain refinement on thermal stability of metastable austenitic steel. Mater. Trans. 2004, 45, 2245-2251. [CrossRef]

34. Zou, Y.; Xu, Y.B.; Hu, Z.P.; Gu, X.L.; Peng, F.; Tan, X.D.; Chen, S.Q.; Han, D.T.; Misra, R.D.K.; Wang, G.D. Austenite stability and its effect on the toughness of a high strength ultra-low carbon medium manganese steel plate. Mater. Sci. Eng. A 2016, 675, 153-163. [CrossRef]

35. Nakada, N.; Syarif, J.; Tsuchiyama, T.; Takaki, S. Improvement of strength-Ductility balance by copper addition in 9\% Ni steels. Mater. Sci. Eng. A 2004, 374, 137-144. [CrossRef]

36. Niino, T.; Inoue, J.; Ojima, M.; Nambu, S.; Koseki, T. Effects of solute carbon on the work hardening behavior of lath martensite in low-carbon steel. ISIJ. Int. 2017, 57, 181-188. [CrossRef]

37. Nakashima, K.; Futamura, Y.; Tsuchiyama, T.; Takaki, S. Interaction between dislocation and copper particles in Fe-Cu alloys. ISIJ. Int. 2002, 42, 1541-1545. [CrossRef]

38. Guo, Z.; Sha, W. Quantification of precipitation hardening and evolution of precipitates. Mater. Trans. 2002, 43, 1273-1282. [CrossRef]

39. Nakada, N.; Yamashita, T.; Syarif, J.; Tsuchiyama, T.; Takaki, S. Effect of Cu addition on formation of reversed austenite and hardness in 9\% Ni steels. J. Iron. Steel Res. Int. 2003, 89, 1050-1056. [CrossRef]

40. Bleck, W.; Guo, X.; Ma, Y. The TRIP effect and its application in cold formable sheet steels. Steel Res. Int. 2017, 88, 1700218. [CrossRef]

41. Fischer, F.D.; Sun, Q.-P.; Tanaka, K. Transformation-induced plasticity (TRIP). Appl. Mech. Rev. 1996. [CrossRef]

42. Syarif, J.; Handra, N.; Sajuri, Z.; Omar, M.Z. Change in Tensile Properties of Dual-Phase Steels by Cu Addition. Trans. Indian Inst. Met. 2018, 71, 513-519. [CrossRef]

43. Cao, Y.; Ahlström, J.; Karlsson, B. The influence of temperatures and strain rates on the mechanical behavior of dual phase steel in different conditions. J. Mater. Res. Technol. 2015, 4, 68-74. [CrossRef]

44. Takaki, S.; Ngo-Huynh, K.-L.; Nakada, N.; Tsuchiyama, T. Strengthening mechanism in ultra low carbon martensitic steel. ISIJ Int. 2012, 52, 710-716. [CrossRef]

45. Zhuang, X.; Ma, S.; Zhao, Z. Effect of particle size, fraction and carbide banding on deformation and damage behavior of ferrite-cementite steel under tensile/shear loads. Model. Simul. Mater. Sci. Eng. 2016, 25, 15007. [CrossRef]

(C) 2020 by the authors. Licensee MDPI, Basel, Switzerland. This article is an open access article distributed under the terms and conditions of the Creative Commons Attribution (CC BY) license (http://creativecommons.org/licenses/by/4.0/). 